A suggestion that the collection of living animals should be transferred to the Government Zoological Gardens at Dehiwala was strenuously opposed by the Committee of Management, and instead efforts are being made to improve and extend this museum zoo, which is an invaluable educational adjunct to the mounted collections. The Ethnological Department has begun a survey of the native population, and various expeditions have been carried out for a study of cultural institutions and social and economic conditions.

\section{Trachoma in Tunisia}

IN a recent study (Thèse de Paris, 1938, No. 142), Dr. C. Koskas states that trachoma was probably imported into Tunisia by immigrants from North Africa, Italy, Malta and Spain. Although it is a notifiable disease, the natives, who do not recognize the gravity of the condition, evade the law, and comparatively few cases are actually notified. The only means of determining in any way the trequency of the disease is by medical examination of school children or of recruits for the army. There is no doubt, however, that infection rarely occurs in adults or in the schools; but that it is usually contracted in the early months of life. The incidence of the disease is much higher in the south where the climate is hot, the sirocco violent and frequent, the atmosphere laden with dust and sand, and the inhabitants poverty stricken and underfed than in the north of Tunisia. Flies play an important part in the transmission of the disease, as was shown by Nicolle and Cuenod in 1921, Petit in 1925 and Mme. Delanoe in 1930 ; but race does not influence the incidence or gravity of the disease. Good work has been done by the establishment of ophthalmic departments where free advice and treatment are given.

\section{Electrical and Allied Manufacturers' Association}

THE eleventh edition of a pamphlet giving information about the British Electrical and Allied Manufacturers' Association (BEAMA) has just been published. The president of the Association is the Earl of Derby. The objects of the Association are to foster and protect the electrical and allied industries in Great Britain. It aims at securing the co-operation of every firm in the electrical and allied industries so that, by co-operative action, it can speak for the whole of those industries on all matters affecting them. The Standardization Committee acts as a centre and clearing house for the many activities of its members in connexion with standardization and the British Standards Institution. The Association's numerous technical and other committees are continuously at work in the interests of the sections by which they are appointed and of the members generally. The address of the Association is 36 Kingsway, W.C.2.

\section{Earthquake in Bulgaria on November 6}

AT approximately $21 \mathrm{~h}$. G.C.T., an earthquake damaged property and felled chimneys in the Gabrovo district in north Bulgaria. Many people were alarmed, but no loss of life is reported. Bulgaria as a whole must be considered an earthquake country, though the north has not been subjected to so many as the south. The chief epicentral region in north Bulgaria is around Timovo, and the next in importance is the Déli-Orman. Further information concerning the shock will probably come shortly from Dr. K. T. Kiroff and his colleagues at the observatory at Sofia.

\section{Japanese Earthquake of November 5}

As earthquake was experienced in the Miyagi Prefecture in the north-east of the main island of Japan at $8 \mathrm{~h} .44 \mathrm{~m}$. G.C.T. (5.44 p.m. local time), and an after-shock followed two hours later. The focus appears to have been at some considerable depth, as the shock was felt in the four Prefectures of Miyagi, Iwate, Fukushima and Ibaragi, and even as far as Tokyo, though no damage is reported from this city. In this part of Japan there is a well-defined belt of earthquake epicentres stretching from Kamagata through Wakamatsu and Utsunomiya to Choshi. Severe earthquakes happened in the north end of this belt in 1893,1894 and 1895, the last two from the same epicentre, though more recently strong earthquakes have been more frequent along parallel belts to the south, west, north, and seaward of this. The shock which was recorded on seismographs at Kew and elsewhere in Great Britain at $8 \mathrm{~h} .55 \mathrm{~m} .59 \mathrm{~s}$. G.C.T. and mentioned in the general press in connexion with the above, was not due to the Japanese earthquake but was from some epicentre at about $87^{\circ}$ from $\mathrm{Kew}$, though the exact location is not yet determined.

\section{Commonwealth Fund Fellowships}

THE total number of Commonwealth Fund Fellowships offered for award in 1939 is thirty-four. These fellowships are tenable at certain American universities. Candidates for Ordinary Fellowships must be of British descent who are domiciled in the United Kingdom of Great Britain and Northern Ireland, and are degree graduates of recognized universities therein. Candidates for Dominion Fellowships must be of British descent from the British Dominions, who have studied, but not necessarily graduated, at a university in the United Kingdom of Great Britain and Northern Ireland, who are degree graduates of a recognized university in a British Dominion or Colony. Candidates for Service Fellowships must be of British descent and must hold appointments overseas under the British Government, or the Government of India, or the Government of a British Dominion, Colony, Protectorate or Mandated Territory; and those for Home Civil Service Fellowships must be holding appointments in the Home Civil Service. None of these fellowships is open to women. Further information can be obtained from the Secretary to the Committee, Commonwealth Fund Fellowships, 35 Portman Square, London, W.1.

\section{International Union of Geodesy and Geophysics}

THE International Union of Geodesy and Geophysics will hold its seventh general assembly in Washington, U.S.A., on September 4-15, 1939. 
Invitations have been extended on behalf of the President of the United States to the participating countries to be represented by delegates on this occasion. The American Geophysical Union is the American section of the International Union of Geodesy and Geophysics, and its executive committee is the Committee on Geophysics of the National Research Council. The Council is collaborating with the American Geophysical Union as host to the assembly. The last general assembly of the International Union was held at Edinburgh, Scotland, in September 1936. The thirty-five nations at present adhering to the International Union are : Argentina, Belgium, Brazil, Bulgaria, Canada, Colombia, Chile, Czechoslovakia, Denmark, Egypt, Finland, France, Germany, Great Britain, Greece, Holland, Hungary, Indo-China, Italy, Japan, Morocco, Mexico, New Zealand, Norway, Peru, Poland, Portugal, Rumania, Siam, Spain, Sweden, Switzerland, Union of Soviet Socialist Republics, United States, and Yugoslavia.

\section{Another Large Sunspot}

THe giant sunspot which crossed the sun's disk between October 5 and 18 broke up before its return, due at the eastern limb on November 2. Meanwhile, another large spot had formed in solar longitude $273^{\circ}$ and in latitude $9^{\circ}$ south. This spot came round the limb on November 4, though it was not completely seen until the following day, when its area was 2000 millionths of the sun's hemisphere. The time of central meridian passage was November 10.8 U.T.; its date of disappearance around the western limb will be November 17 .

\section{Announcements}

Dr. W. D. LANG, keeper of the Department of Geology of the British Museum (Natural History), is to retire on December 29. The principal trustees of the Museum have appointed Mr. W. N. Edwards, deputy keeper of the Department, to succeed Dr. Lang. Mr. Edwards was born in 1890 and was a scholar of Christ's College, Cambridge. He entered the British Museum (Natural History) as an assistant in the Department of Geology in 1913 and became deputy keeper in 1931. He is an authority on fossil plants and has travelled extensively.

DR. T. S. WHEELER, principal of the Royal Institute of Science, Bombay, has left India and will shortly take up his new appointment as State Chemist, Eire.

Mr. J. Wickham Murray, secretary of the Asso. ciation of Teachers in Technical Institutions, has been appointed an official for higher education by the executive of the National Union of Teachers.

Ar the anniversary meeting of the Mineralogical Society on November 3, the following were elected officers: President and Editor of the Journal, Dr. L. J. Spencer ; Vice-Presidents, Prof. C. E. Tilley and Lieut.-Colonel W. Campbell Smith; Treasurer,
F. N. Ashcroft ; General Secretary, G. F. Claringbull ; Foreign Secretary, Sir Thomas Holland.

A symposium on "Gas Temperature Measurement" will be held by the Institute of Fuel in the lecture theatre of the Institution of Electrical Engineers, Savoy Place, Victoria Embankment, W.C.2, on December 2. It will commence at 10.30. Further information can be obtained from the Secretary, Institute of Fuel, 53 Victoria Street, London, S.W.1.

The Royal Sanitary Institute Congress of 1939 will be held at Scarborough on July 3-8 and the Congress of 1940 at Torquay on July 1-6. Further information can be obtained from the Secretary of the Institute, 90 Buckingham Palace Road, London, S.W.1.

A Fourxh Farming Conference will be held at Oxford under the joint auspices of the School of Rural Economy, the Agricultural Economics Research Institute and the Institute for Research in Agricultural Engineering of the University of Oxford on January 3-5, 1939. Further information can be obtained from the Conference Secretary, 10 Parks Road, Oxford.

THE Far Eastern Association of Tropical Medicine will hold its tenth Congress at Hanoï, Tonkin, on November 24-30, when discussions will be held on feeding in deficiency diseases, cholera, malaria, plague, tuberculosis, venereal disease, surgery, diseases common to man and animals, parasitology and local anthropological characteristics.

Tre next International Congress of Surgery will be held in 1941 at Stockholm under the presidency of Dr. Leopold Mayer.

THE Congress of Comparative Pathology will be held in Rome on May 15-20, 1939, under the presidency of Prof. Rondoni, director of the Cancer Institute at the University of Milan. The following subjects will be discussed: ultra-virus diseases; heredity in pathology; the association of antigens. and their function; regressive processes in plants The secretary of the Congress is Prof. Zavagli at Consiglio Nazionale delle Ricerche, Piazzale delle Scienze, Rome, from whom further information can be obtained.

The Home Secretary proposes to make regulations under the Factory Act 1937 extending the provisions of Section 66 to compressed air illness. Copies of the draft regulations may be ordered through any bookseller from H.M. Stationery Office.

The Pasteur Institute of Algiers, of which Dr. Edmond Sergent is director, has been authorized by the French Government to sell a serum against scorpions prepared from immunized horses.

Erratum. In Nature, November 5, p. 843, "Origin of the Solar System"; last line of first paragraph, for "internal" read "external". 